\title{
Analysis of Employees' Perception and Job Satisfaction: A study of HRM practices in Post Offices
}

\author{
Dr. Monika Mittal ${ }^{1}$, Dr. Meenu Rattan ${ }^{2}$ \\ ${ }^{1}$ Assistant Professor in Commerce, GGDSD College, Sector-32, Chandigarh. \\ Monika_752@yahoo.com \\ ${ }^{2}$ Assistant Professor in Commerce, DAV College, Sector-10, Chandigarh. \\ Meenu.rattan@gmail.com
}

\begin{abstract}
Satisfying employees at work places has ever been a crucial task before any of the organizations to ensure the success of the organization. Further, the level of job satisfaction is affected by a wide range of variables relating to individual, social, cultural, organizational and environmental factors. The present study examines the level of satisfaction of employees of post offices around the Tricity (Chandigarh, Panchkula and Mohali). The study highlights various factors determining the employees' satisfaction with the job and some recommendations have also been made to enhance their satisfaction level. Data are obtained from postal assistants through structured questionnaire and used to illustrate their perception towards their organization with the help of factor analysis.
\end{abstract}

\section{Indexing terms/Keywords}

Keywords: Post office, Job satisfaction, factor analysis, rewards and growth.

\section{Academic Discipline And Sub-Disciplines}

Management

\section{SUBJECT CLASSIFICATION}

HRM Classification

\section{TYPE (METHOD/APPROACH)}

Convenient randomized sample method, Factor analysis, weighted average scores and percentages.

\section{Council for Innovative Research}

Peer Review Research Publishing System

Journal: International Journal of Management \& Information Technology

Vol. 5, No. 3

editor@cirworld.com

www.cirworld.com, member.cirworld.com 


\section{INTRODUCTION}

It is well known, that work occupies an important place in the life of human beings. The work performance of the individual depends upon the level of satisfaction he gets at the work place and further, the level of job satisfaction is affected by a wide range of variables relating to individual, social, cultural, organizational and environmental factors. Job satisfaction can also be seen within the broader context of the range of issues which affect an individual's experience of work or their quality of work life.

For success of an organization employee satisfaction is essential. The employee who has no interest in his or her field or the position in which he or she begins in a job may initially put forth his or her best effort. However, this employee will often become bored with the work because there is no intrinsic motivation to succeed.

Postal department is one of oldest department of the country serving a huge mass of citizens. The recruitment process is well established and well defined. It has passed through many transition phases. People are recruited at root level and are promoted to higher level through departmental exams as well as seniority. Training is given to the employees from time to time to enhance their skills and knowledge. Incentives are also given to employees for bringing business to the organization.

The present study is a modest attempt to identify the level of job satisfaction of employees of post offices in the Tricity. Various factors like work procedure, role clarity, salary \& incentives, promotions, recognition at work etc. has been taken into consideration.

\section{OBJECTIVES OF THE STUDY}

The study aims i) to delve into adequacy and effectiveness of Job satisfying factors in Post offices and ii) to assess the respondents' level of satisfaction with regards to various HRM practices being followed by post offices.

\section{AREA OF STUDY}

The study has been carried out in the post offices of the tricity i.e. Chandigarh, Panchkula and Mohali. Post offices were selected as per convenience.

\section{DATA BASE AND RESEARCH METHODOLOGY}

To satisfy the objectives, the primary data has been collected with the help of a structured questionnaire. A convenient randomized sample of 60 employees of postal assistant rank was selected. Factor analysis, weighted average scores and percentages have been used to draw the meaningful inferences from the study.

\section{DATA ANALYSIS AND INTERPRETATION}

An understanding of the employees' perception of the HRM practices being followed in their organization is very crucial as it would enable the organization to identify the lacking areas to implement such practices in an effective and efficient manner. In the following section, an attempt has been made to understand employees' perceptions towards the job satisfying factors with regards to HRM practices of post offices.

The study used factor analysis to analyze the level of job satisfaction of post offices' employees.

Factor analysis is one of the techniques of multivariate data analysis which aims at reduction and summarization of the large number of variables in order to identify some common dimensions i.e. factors. In order to achieve this purpose, a list of 15 variables of job satisfaction was provided to the 60 respondents who were then asked to rate these variables on the five point Likert's scale ranging from highly satisfactory variables to highly dissatisfactory.

\section{Table 1. List of variables}

\begin{tabular}{|l|l|}
\hline Serial No. & Variables \\
\hline V 01 & Work procedures are well defined \\
\hline V 02 & Roles are clearly specified \\
\hline V 03 & Employees are involved in organizational activities \\
\hline V 04 & Salary structure is satisfactory \\
\hline V 05 & Incentive system is adequate \\
\hline V 06 & Training is imparted for skill upgardation of employees \\
\hline V 07 & Organization is concerned with development of its employees \\
\hline V 08 & Performance evaluation system is effective and continuous \\
\hline V 09 & Promotions and rewards are performance based \\
\hline V 10 & Motivation is given to employees to be innovative \\
\hline V 11 & Employees are well consulted for job related matters \\
\hline V 12 & Due recognition is given to employees for organization's success \\
\hline
\end{tabular}




\begin{tabular}{|l|l|}
\hline V13 & Employees are indulged in flattery to win supervisors' favor \\
\hline V14 & Organization employs proper grievance handling mechanism \\
\hline V 15 & Retirement benefits provided to employees are sufficient \\
\hline
\end{tabular}

Further, Factor analysis was carried out on the above mentioned variables and using principle component method along with Varimax rotation, four factors could be extracted as follow

Table 2. List of Factors

\begin{tabular}{|c|c|c|c|}
\hline Factors No. & Factor Name & Statements & Score \\
\hline \multirow[t]{5}{*}{1} & Reward Factor & $\begin{array}{l}\text { V03 } \\
\text { Employees are involved in organizational activities }\end{array}$ & .599 \\
\hline & & $\begin{array}{l}\text { V } 04 \\
\text { Salary structure is satisfactory }\end{array}$ & .946 \\
\hline & & $\begin{array}{l}\mathrm{V} 05 \\
\text { Incentive system is adequate }\end{array}$ & .771 \\
\hline & & $\begin{array}{l}\text { V } 14 \\
\text { Organization employs proper grievance handling } \\
\text { mechanism }\end{array}$ & .599 \\
\hline & & $\begin{array}{l}\text { V } 15 \\
\text { Retirement benefits provided to employees are sufficient }\end{array}$ & .946 \\
\hline \multirow[t]{4}{*}{2} & $\begin{array}{l}\text { Role } \quad \& \\
\text { Recognition } \\
\text { Factor }\end{array}$ & $\begin{array}{l}\text { V } 01 \\
\text { Work procedures are well defined }\end{array}$ & .825 \\
\hline & & $\begin{array}{l}\text { V } 02 \\
\text { Roles are clearly specified }\end{array}$ & .881 \\
\hline & & $\begin{array}{l}\text { V } 12 \\
\text { Due recognition is given to employees for organization's } \\
\text { success }\end{array}$ & .824 \\
\hline & & $\begin{array}{l}\text { V } 13 \\
\text { Employees are indulged in flattery to win supervisors' favor }\end{array}$ & .878 \\
\hline \multirow[t]{3}{*}{3} & Motivation Factor & $\begin{array}{l}\text { V } 09 \\
\text { Promotions and rewards are performance based }\end{array}$ & .843 \\
\hline & & $\begin{array}{l}\text { V } 10 \\
\text { Motivation is given to employees to be innovative }\end{array}$ & .849 \\
\hline & & $\begin{array}{l}\text { V } 11 \\
\text { Employees are well consulted for job related matters }\end{array}$ & .783 \\
\hline \multirow[t]{3}{*}{4} & Growth Factor & $\begin{array}{l}\text { V } 06 \\
\text { Training is imparted for skill upgardation of employees }\end{array}$ & .864 \\
\hline & & $\begin{array}{l}\text { V } 07 \\
\text { Organization is concerned with development of its } \\
\text { employees }\end{array}$ & .526 \\
\hline & & $\begin{array}{l}\text { V } 08 \\
\text { Performance evaluation system is effective and continuous }\end{array}$ & .831 \\
\hline
\end{tabular}

Further, in order to find out the significance level of factors, the factor-wise average scores (From the five point likert scale data) were calculated and ranked accordingly. The average scores were further used to rank the factors as shown in the following tables-

\section{Table 3. Average scores of variables}

\begin{tabular}{|l|l|c|}
\hline Serial No. & Variables & Average Scores \\
\hline V 01 & Work procedures are well defined & 3.6500 \\
\hline V 02 & Roles are clearly specified & 3.7167 \\
\hline V 03 & Employees are involved in organizational activities & 2.8733 \\
\hline V 04 & Salary structure is satisfactory & 3.2500 \\
\hline V 05 & Incentive system is adequate & 3.0500 \\
\hline V 06 & Training is imparted for skill upgardation of employees & 3.8667 \\
\hline V 07 & Organization is concerned with development of its employees & 3.2333 \\
\hline V 08 & Performance evaluation system is effective and continuous & 3.4833 \\
\hline
\end{tabular}




\begin{tabular}{|l|l|c|}
\hline V 09 & Promotions and rewards are performance based & 3.0167 \\
\hline V 10 & Motivation is given to employees to be innovative & 3.2167 \\
\hline V 11 & Employees are well consulted for job related matters & 3.3667 \\
\hline V 12 & $\begin{array}{l}\text { Due recognition is given to employees for organization's } \\
\text { success }\end{array}$ & 3.6512 \\
\hline V 13 & Employees are indulged in flattery to win supervisors' favor & 3.7267 \\
\hline V 14 & Organization employs proper grievance handling mechanism & 2.8833 \\
\hline V 15 & Retirement benefits provided to employees are sufficient & 3.2511 \\
\hline
\end{tabular}

Table 4.Factor wise average scores

\begin{tabular}{|l|l|l|}
\hline Rank & Factors & Average scores \\
\hline 4 & Reward & 3.04 \\
\hline 1 & Role \& Recognition & 3.68 \\
\hline 3 & Motivation & 3.20 \\
\hline 2 & Growth & 3.53 \\
\hline
\end{tabular}

\section{EXPLANATION OF FACTORS}

Findings show that majority (92\%) of the employees is aware of the goals of the organization and they also agreed that organizational goals are identified after careful analysis of the competitors. Majority (91\%) of the employees are familiar with the recruitment process at various level of the organization. Few employees are not satisfied as they feel that minimum qualification required is very less.

\section{ROLE AND RECOGNITION}

Clarity in role and recognition of work of employees has been perceived by employees as the most important factor for job satisfaction as it has been ranked first with an average score of 3.68.role and recognition includes $\mathrm{V} 01$ "Work procedures are well defined" V 02 "Roles are clearly specified" V 12 "Due recognition is given to employees for organization's success" V 13 "Employees are indulged in flattery to win supervisors' favor". It shows that employees give importance to role clarity and well defined work procedures at work place. Respondents agree that organization have well defined procedure of work in the organization. Majority of the respondents agree that employee has clear-cut roles in the organization and some disagree with the statement. Some respondents (34\%) complain that at the time of personal interview favoritism prevails in selection process.

\section{GROWTH FACTOR}

Growth has been ranked second by the employees with average score of 3.53. It includes $\vee 06$ "Training is imparted for skill upgardation of employees" V 07 "Organization is concerned with development of its employees" V 08 "Performance evaluation system is effective and continuous". It indicates that employees are given training to its employees for skill up gradation.

Respondent are satisfied with the training facilities of the organization. Employees are sent for training at regular intervals. It is the only aspect of the HRM with which majority (96\%) of the respondents are satisfied. Training is given by both on the job and off the job methods. Training duration varies from 15 days to 5 months. Performance evaluations are done by using ACR method. Only adverse remarks are conveyed not positive ones. It discourages the employees.

\section{MOTIVATION FACTOR}

Motivation has been ranked third by the employees with an average score of 3.20 . it includes $\mathrm{V} 09$ "Promotions and rewards are performance based" V 10 "Motivation is given to employees to be innovative" V 11 "Employees are well consulted for job related matters". It indicates that both monetary and non monetary methods are used for motivation of employees. Promotion is not based on performance but on seniority. Respondents are of the view that employees are not encouraged to be innovative on the job. There is conflicting opinion of the respondents to the statement that top management praises employees for good performance. Equal number agrees to and disagrees to this statement.

\section{REWARD FACTOR}

Reward factor is considered least important by employees as it has been fourth with an avg. score of 3.04 . It includes V03 "Employees are involved in organizational activities" .V 04 "Salary structure is satisfactory" V 05 "Incentive system is adequate" V 14 "Organization employs proper grievance handling mechanism" V 15 "Retirement benefits provided to employees are sufficient". It shows that monetary factors are considered most important. Attractive rewards and incentives lead to higher job satisfaction among the employees. Majority of respondents (63\%) are not satisfied with the present pay system. Same is the case with the incentive system. This may be due to the reason that incentives are not given on all positions. So employees indulge themselves in flattery of their bosses to be posted on these positions. Majority of the 
respondents $(58 \%)$ say that there is no suitable grievance handling systems in the organization. Their problems are not heard.

\section{CONCLUDING REMARKS}

It can be concluded from the study that postal department has well defined process of recruitment and selection. Majority of the respondents agree to this statement. It has clear cut procedures at work. Employees are given induction training as well as training during the job to upgrade their skills. Still efforts are required to make improvement in some areas like performance evaluation, promotions, and incentives. Following are a few recommendations to raise the level of satisfaction among the employees of post offices to up-grade their efficiency and effectiveness:

- Minimum qualification required for the entry level should be raised.

- Performance evaluation should be done more frequently.

- Both positive and negative remarks should be communicated to the employees.

- Pay scales should be made more attractive.

- Promotion should be based on both seniority and performance.

Thus, well defined recruitment policy and most importantly effective implementation of the policies are very much required for the satisfaction of the employees of any organization and whatever efforts have already been made in this direction, there always remain scope to do better. Selecting best employees is important but retaining best employees is crucial for the sustainable growth of an organization.

\section{REFERENCES}

[1] Spector, P.E. (1997). "Job satisfaction: Application, assessment, causes and consequences", Thousand Oaks, CA: SAGE.

[2] Viswesvaran. Chockalingam and Deshpande, P. Satish (1996). "Ethics, success, and job satisfaction: A test of dissonance theory in India", Journal of Business Ethics, volume-15, Issue-10, pp. 1065-1069.

[3] Saari, L. M. and Judge T.A. (2004) "Employee attitude and job satisfaction”, Human Resource Management, 43, 395-407.

\section{Author' biography with Photo}

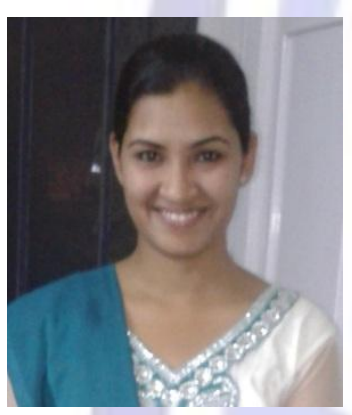

\section{Dr. Meenu Rattan}

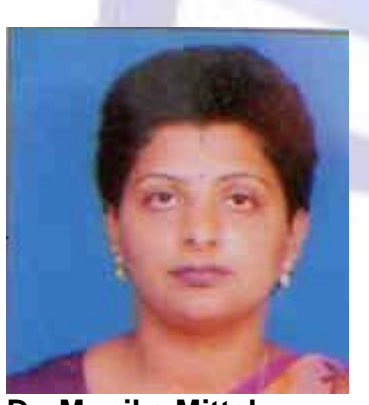

Dr. Monika Mittal
Dr.Meenu Rattan is an Assistant Professor in the department of Commerce, DAV College, Sector-10, Chandigarh. She has done her post graduation and doctorate from Guru Nanak Dev University, Amritsar. Her special interests are in the field of Banking and Finance. She has presented more than dozen papers in a number of national level seminars and conferences including international conferences and has nine articles to her credit published in reputed national and international journals such as Decision, Development in Practice, American Journal of Social and Management Sciences, InternationalJournal of Economics and Research.

Dr. Monika Mittal is an Assistant Professor in the department of Commerce, GGDSD College, Chandigarh. She has done her post graduation and doctorate from the Panjab University, Chandigarh. Her special interests are in the field of Banking and Finance. She has presented papers in a number of national level seminars and conferences including international conferences and has some articles to her credit published in reputed national journals. 